\title{
ISOLATION OF FUNGUS FROM ROOTS OF WATER HYACINTH AND CELLULASE PRODUCTION BY THE MICROORGANISM FROM CARDBOARD WASTE
}

\author{
Sumit Sharma ${ }^{1}$, Saurabh Jyoti Sarma ${ }^{1 *}$ Satinder Kaur Brar ${ }^{2,3}$ \\ ${ }^{1}$ Department of Biotechnology, Bennett University, Greater Noida (UP), 201310, India \\ ${ }^{2}$ INRS-ETE, Université du Québec, 490, de la Couronne, Québec, Canada G1K 9A9 \\ ${ }^{3}$ Department of Civil Engineering, Lassonde School of Engineering, York University, \\ North York (Toronto), Canada, M3J 1P3.
}

\begin{abstract}
Bioethanol production from agro-industrial waste is becoming a major research area for alternative fuel. The cellulase enzyme is the key ingredient used for the cellulosic bioethanol fermentation process. India is abundant in cellulosic resources that come from paper and pulp industries. Single-use newspaper and packaging cardboards constitute a significant portion of cellulosic wastes. Here in this study, an industrial enzyme cellulase was produced from single-use newspaper and cardboard wastes. A fungus was isolated (THS8) from the root of the water hyacinth collected from an abundant pond located near Badoli village, Faridabad (India). The fungus was used to do a comparative study for cellulase production by using different substrates such as pure carboxymethyl cellulose (CMC), cardboard (CB), coated cardboard (CBC) and newspaper (NP). The maximum cellulase activity $0.149 \mathrm{FPU}$ (Filter paper unit)/ml was estimated in cardboard (20g/l) grown in MW (Mandel Weber) medium. Likewise, a total of $60 \%$ degradation of the cardboard was observed after 7 days of incubation at $30^{\circ} \mathrm{C}$ with 0.27 FPU/ml optimized at CB 20g/l. This demonstrates the feasibility of using cardboard as a less expensive feedstock, which is usually dumped after unpacking items in households and industries, to produce cellulase enzyme by the isolated microorganism.
\end{abstract}

\section{Keywords}

Cardboard, Water hyacinth, Trichoderma, Cellulase, FPU.

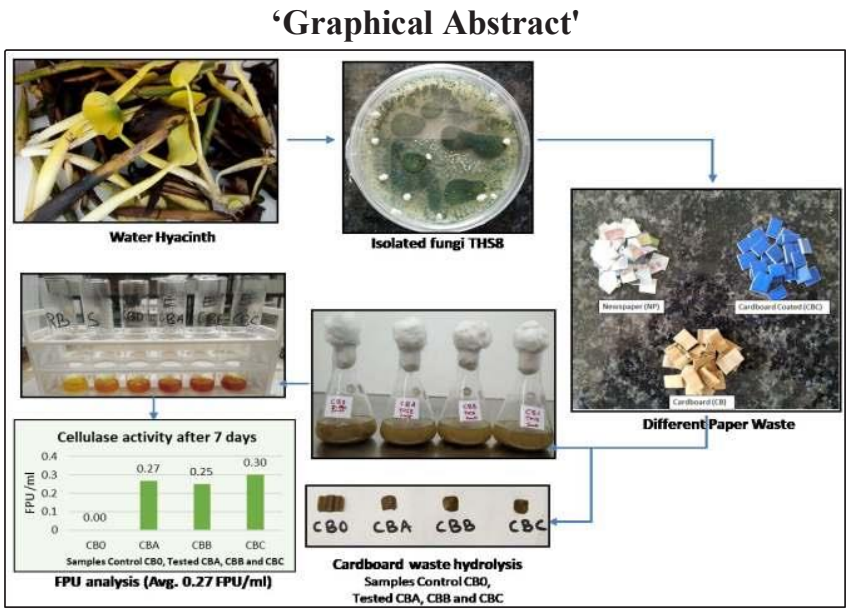

1. Introduction

Lignocellulosic biomass is a kind of renewable resource present in abundant quantities in India. Rice straw, wheat straw, sugar cane bagasse, etc. are different types of lignocellulosic biomasses. The burning of such biomass is a major concern due to resulting air pollution. Bioethanol production from lignocellulosic biomass is a suitable way to process it into a useful product. Bioethanol can be blended with fuel and have advantages of less greenhouse gas emission. The whole process of bioethanol production includes pretreatment, hydrolysis, and fermentation. Improvements in the enzymatic hydrolysis can also make it more feasible for commercialization. As the cellulosic biorefineries are setting up in India, the demand of cellulase enzyme is increasing day-by-day. So, a cost-effective process can reduce the production cost using cheaper or waste cellulosic sources for cellulase production. Cellulase is a well-studied enzyme which converts cellulose to glucose by using a cocktail CBHs (Cello-bio-hydrolases) and glucosidase. Therefore, this study is focused on finding a way 
CONTACT *Corresponding author: saurabh.sarma@bennett.edu.in

Color versions of one or more of the figures in this article can be found online at www.ste.org

(C) 2020 Save the Environment 

to use the cheapest cellulosic waste for cellulase production. A waste biomass can be applied as raw material to reduce waste pollution as well as production cost, which can boost the bioeconomy of the country.

Lignocellulosic biomass is a renewable, abundant and costeffective bioresource to produce bioproducts [1]. It comes from the non-edible part of the feedstock (rice straw, wheat straw, sugarcane bagasse, cotton stalk) so its application does not affect the food supply [2]. There are many challenges of this process like poor sugar recovery, high enzyme cost, long hydrolysis time, less inhibitor tolerant microbes [3]. Lignocellulosic biomass is composed of cellulose, hemicellulose and lignin, and ash in a variable amount in different kinds of biomasses. Cellulose is a major part of biomass, which contains long chains of glucose sugar that are further utilized for fermentation into ethanol [4]. Hemicellulose is made up of a combination of sugars like xylose, arabinose, and mannose [5]. Lignin is a complex polymer that gives strength to the biomass and highly crosslinked phenols are present in it [6].

Enzymatic hydrolysis is the process of conversion of cellulose to glucose by the action of cellulase enzyme. Cellulase is made up of three main enzymes exo- $\beta$-glucanase, endo- $\beta$-glucanase and $\beta$-glucosidase [7]. Similarly, hemicellulase is composed of mostly xylanase. Trichoderma reseei and Aspergillus nigerare the major micro-organisms studied and used to produce cellulase and xylanase enzyme [7]. Meanwhile, the cost of the enzyme is too high so that the improvement in the enzyme activity and in-house production strategies are used to find a better solution for a reduction in the cost of the enzyme. There are various methodologies used for enzyme activity improvement, such as optimization of $\mathrm{pH}$ and temperature [8], immobilization methods [9], the addition of surfactants [10], chemical or radiation mutation [11,12], mild sonication [13], and enzyme cocktail from different species [14] to reduce the time and cost of the process.

Fermentation of cellulosic biomass can be done with and after enzymatic hydrolysis process. Separate hydrolysis and fermentation (SHF), simultaneous saccharification and fermentation (SHF), simultaneous saccharification and cofermentation are three approaches [2] used with hydrolysis. Hydrolysis and fermentation are separately carried out in the case of SHF. SSF includes hydrolysis along with fermentation of only hexose sugar and SSCF includes the hydrolysis and fermentation of both hexose and pentose sugars [15]. Consolidated bioprocessing (CBP) is the new method in which one single micro-organism like Clostridium processes the cellulose directly into ethanol by the release of enzyme [16]. Saccharomyces cerevisiae is the primary source of microbe used to produce ethanol due to its robustness [17]. Some other thermo-tolerant yeast Kluveromyces marxianus is also used (mostly for the SSF) to carry out the process at high temperatures (nearly $45^{\circ}$ ) [18]. Zymomonas mobilis is a bacterium that can metabolize sugars into ethanol [19]. Clostridium themocellum is the best thermophilic bacterium for the CBP process [16] but the yield in both the bacterium is lower than the yeast. Pentose fermenting microorganismslike Pichia stipitis, Pachysolentennophilus, and Candida shehataare also used for xylose to ethanol production. Pichia stipitis is preferred because it does not produce any byproduct, rather has lower ethanol and $\mathrm{pH}$ tolerance [20].

Co-fermentation of hexose and pentose is carried out by metabolically engineering the strain. Metabolic engineering of the Saccharomyces cerevisiae for xylose to ethanol production can be achieved by the transfer of xylose reductase enzyme-encoding (XR) gene and xylose dehydrogenase enzyme-encoding $(\mathrm{XDH})$ genes into Saccharomyces cerevisiae [21]. There is a co-factor imbalance issue due to which xylitol is produced instead of ethanol. While in the case of xylose isomerase enzyme coding (XI) gene does not have any cofactor imbalance issue and only ethanol is produced [22]. So, SSCF is the advanced technology focused on the bioethanol production from lignocellulosic biomass. The purpose of the present study was to find a novel isolate from a non-agriculturalarea filled with water hyacinth and to produce cellulase enzyme from different kinds of wastes.

\section{Material andMethods}

\subsection{Sample collection}

The water hyacinth sample was selected for isolation of micro-organism because of softwood biomass and highwater content. It was suggested as the degrading stem and root can be a source of cellulose-degrading fungi or other micro-organisms. The water hyacinth sample was collected from Badoli village, Faridabad (India).

\subsection{Isolation of cellulose enzyme-producing microbes}

Water hyacinth wet root liquid and the solid portion samples were plated on the PDA (potato dextrose agar) and CMC agar ( $1 \%$ carboxymethyl cellulose agar medium) respectively and incubated at $37^{\circ} \mathrm{C}$ for 4 days. The screening was done by Congo-red zone test [23].

\subsection{Cellulase enzyme production and activity assay}

The cellulase enzyme production medium was MW (Mandel Weber) medium [24]. Initially, isolate S8 was tested for cellulase enzyme activity on the MW medium with CMC 1.5 $\%$ as agar plate and as broth. After that comparative study was done between all isolates for cellulase enzyme activity. All the strains SL1 to SL6 (from a liquid sample) and S8 (from the solid root) were grown in the MW agar medium at $\mathrm{pH} 5$ and kept as the slant. $1 \mathrm{ml}$ of the autoclave distilled water was 
poured into each slant sample, mixed well and $1 \mathrm{ml}$ of the spore solution was inoculated in $50 \mathrm{ml}$ of the MW production medium containing 1\% CMC. After 72 hours, the sample was centrifuged at $8000 \mathrm{rpm}$ for 5 minutes and the supernatant was filtered by a 0.22 -micron filter. Then, filtrate was used for the filter paper assay. FPU assay was done by the Gosh FPA assay protocol [25].

\subsection{Saccharification of cellulose by cellulase crude enzyme extract}

Five gm CMC was added to two $50 \mathrm{ml}$ flasks and autoclaved. After autoclaving and cooling of dried cellulose, $20 \mathrm{ml}$ of the crude enzyme filtrate from the S8 culture was added in the sample (CMCase). Control samples contained20 ml autoclaved water to maintain the moisture up to $80 \%$. Components were mixed well and incubated at $50{ }^{\circ} \mathrm{C}$ for 48 hours. After 48 hours, the CMCase sample became liquefied as compared to control.

\subsection{Cellulase enzyme production in different paper waste} Four kinds of substrates were taken such as newspaper(NP), cardboard (CB), dye coated cardboard (CBC), carboxymethylcellulose (CMC) for the cellulase enzyme production. $20 \mathrm{gm} / \mathrm{l}$ of each substrate in $50 \mathrm{ml}$ fermentation medium was inoculated with spore suspension $(1 \mathrm{ml})$ of the isolate THS 8 with the spore count of $5.32 \times 10^{6}$. Thesamples were incubated at $30^{\circ} \mathrm{C}$ at $120 \mathrm{rpm}$ for 120 hours. After 120 hours, samples were extracted, centrifuged and the supernatant was taken as a crude enzyme sample. FPU assay was done by standard Gosh FPA assay protocol for cellulase enzyme activity.

\subsection{Cardboard substrate utilization}

$2 \%$ of cardboard was mixed with $50 \mathrm{ml} \mathrm{MW}$ medium. Sterilization was done by autoclaving and $1 \mathrm{ml}$ of the spore suspension was inoculated and incubated at $30^{\circ} \mathrm{C}$ for 7 days. After 7 days, the treated biomass was centrifuged, and the crude enzyme extract was taken out. Then, the crude enzyme was tested for FPU analysis per ml of the enzyme sample. The remaining solid substrate was also tested for the degradation and compared with the control sample.

\subsection{Substrate concentration optimization for cellulase production fromcardboard}

The cardboard waste substrate was used from $5 \mathrm{~g} / \mathrm{l}$ to $50 \mathrm{~g} / \mathrm{l}$ concentration (5g/l, $10 \mathrm{~g} / \mathrm{l}, 20 \mathrm{~g} / \mathrm{l}, 30 \mathrm{~g} / \mathrm{l}, 40 \mathrm{~g} / \mathrm{l}$ and $50 \mathrm{~g} / \mathrm{l})$ in MW medium prepared in duplicates for test against control. The samples were sterilized by autoclaving and spore suspension was prepared for the inoculation. The $5.40 \times 10^{6}$ spores per $\mathrm{ml}$ were inoculated as $1 \mathrm{ml}$ suspension in each test sample and $1 \mathrm{ml}$ water in control. Then, it was kept for incubation at $30^{\circ} \mathrm{C}$ for 7 days. After incubation, the crude enzyme was tested for the highest cellulase activity and maximum substrate utilization. Cellulase kinetic activity with respect to enzyme to substrate concentration was applied similar to that used for the growth and consumption of substrate by microbes. Enzyme-specific activity depicted as $\mu^{\mathrm{E}}$ (similar to the specific activity of microbes), a maximum enzyme-specific activity depicted as $\mathrm{m}_{\mathrm{m}}^{\mathrm{E}}$ (similar to $\mathrm{m}_{\mathrm{x}}$ of microbes) and substrate saturation constant depicted as $\mathrm{K}_{\mathrm{s}}{ }^{\mathrm{E}}$ (similar to $\mathrm{Ks}$ for microbes) was calculated by using Michaelis Menten equation [26], where superscript E indicates enzyme.

\subsection{Characterization of isolate TSH8}

THS8 isolate was grown on PDA plate for $4-5$ days at $30^{\circ} \mathrm{C}$. After the development of full mycelium morphological characterization was conducted. Then, a spore suspension was prepared from the plate containing nearly $5.5 \times 10^{9}$ spores per $\mathrm{ml}$ of the suspension. Then, conidial spores were examined under an inverted microscope (EVOS XL imaging system, ThermoFisher).

\section{Result andDiscussion}

\subsection{Isolation of cellulolytic microorganism}

New isolates with the ability to convert cellulose were screened.7 different fungal isolates viz., THSL 1, 2,3,4,5,6 and THS8 were obtained by plating the collected sample on $1 \%$ CMC agar plate. THS8 was isolated from the solid root area sample. Out of which, the S8 isolate was morphologically similar to the fungus Trichoderma sp. A total of 6 liquid isolates SL1 to SL6 and solid sample isolate S8 were selected, which showed cellulose degradation as presented in Figure 1. The potential cellulase producing 7 microbes were screened on Congo red medium containing carboxymethyl cellulose as a substrate with the MW medium. Hendricks et al. also used a similar method for identifying cellulase producing bacterial strains from the soil through Congo-red dye depletion screening [27].After screening with Congo red dye and substrate hydrolysis (Figure 2), the S8 was selected as a potential cellulase producing fungal candidate. As per morphology and growth of the isolate,S8 showed similar characteristics with cellulose-degrading fungus Trichoderma sp. and was selected for further analysis [28]. Congo red test also showed zone on the S8 plate as shown in Figure 2B.

\subsection{Screening based on cellulase activity}

Hydrolysis of cellulose can be visualized on the plate as yellow rings and glucose release from THS8 broth in Figure 3B was determined by DNS test. The filter paper unit (FPU) was also calculated as shown in Table $1[26,29]$. It was observed that sample THS8 showed fungal growth in clumps formation in which these were grown as fungal pellets and did not fully mix with the medium. When allowed to settle, these easily settled as shown in Figure 4. The isolate S8 has an advantage for purification of cellulase which may omit the centrifugation step. The FPU assay results are shown in Table 2 and THS 8 showed maximum activity. 

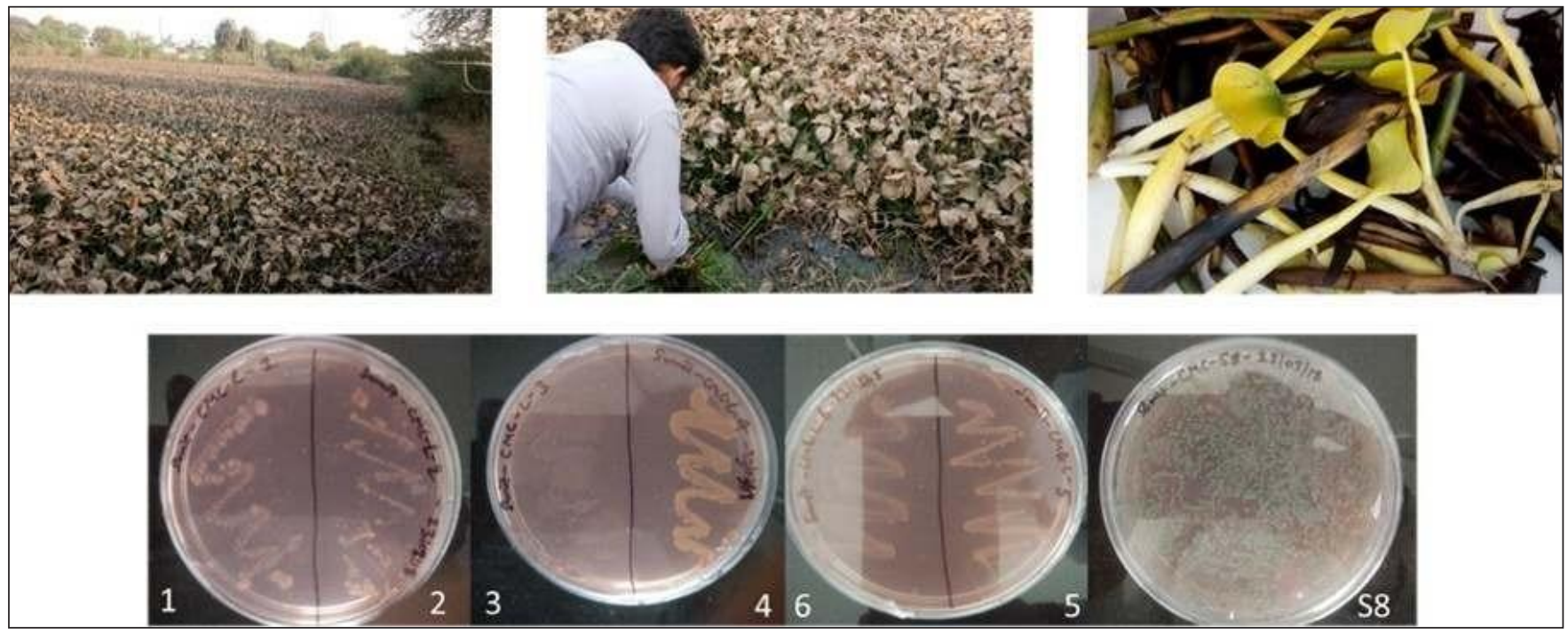

Figure 1: Sample collection of water hyacinth and isolated samples SL1 to SL6 and S8 grown of CMC agar plate with Congo red dye.
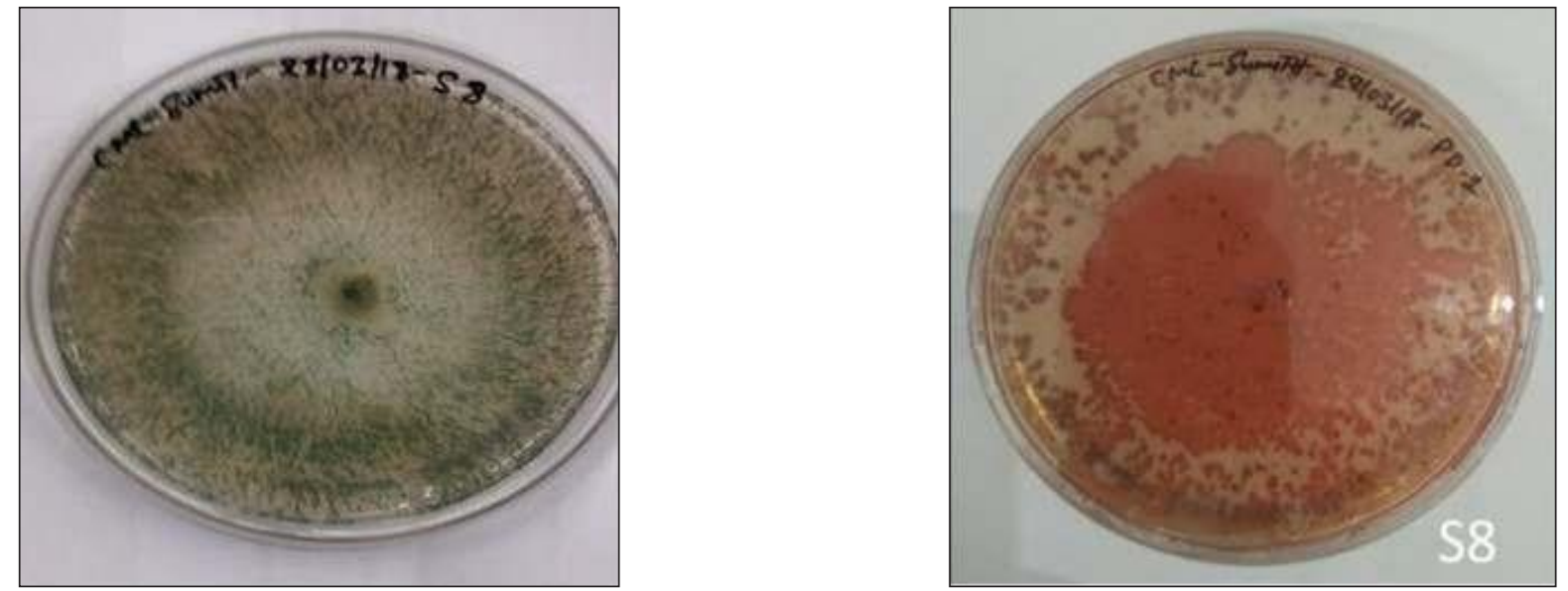

Figure 2: Congo red test showed a clear zone of degraded cellulose by isolate S8.

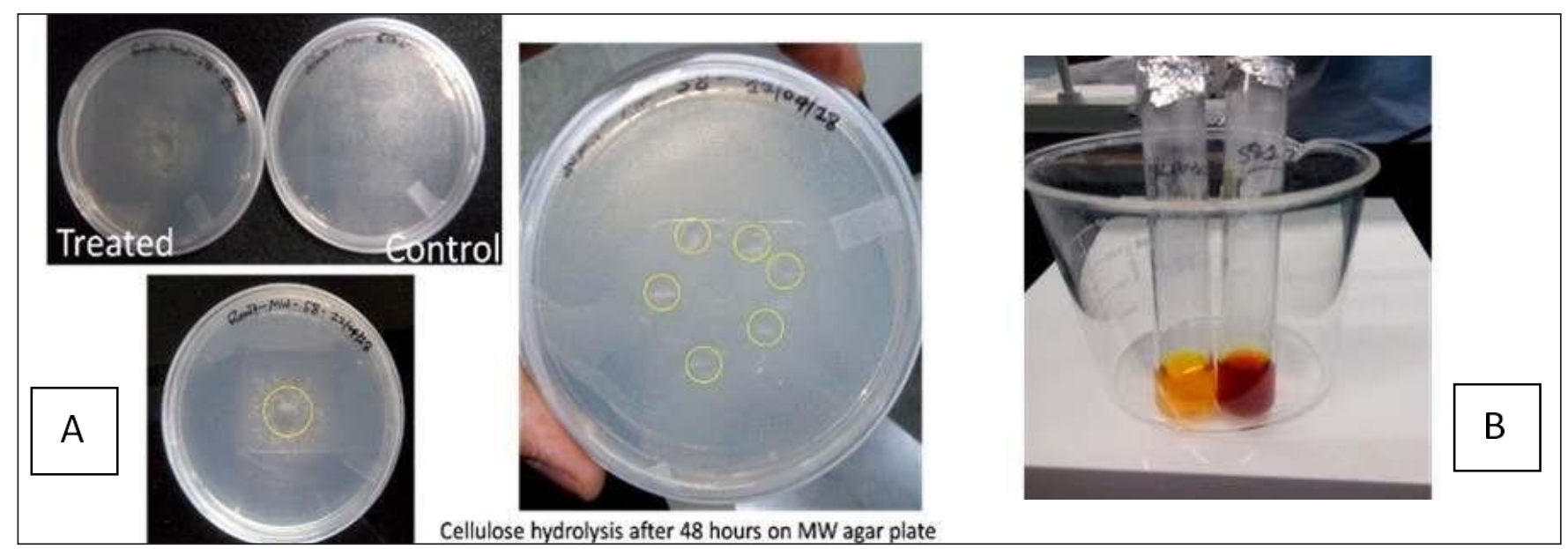

Figure 3: (A) Clear zones as a yellow ring of hydrolyzed cellulose1\% with MW agar plates (B) release of sugar from cellulose observed by DNS method. 
Table 1: FPU and glucose to cellulose conversion.

\begin{tabular}{|l|l|}
\hline Parameters & Values \\
\hline CMC Broth cellulose at Zero-day & $15 \mathrm{~g} / 1$ \\
\hline Glucose produced after 4 days & $3.16 \mathrm{~g} / \mathrm{l}$ \\
\hline Cellulose consumed & $2.84 \mathrm{~g} / \mathrm{l}$ \\
\hline FPU/ml & $0.1670 \mathrm{unit} / \mathrm{ml}$ \\
\hline
\end{tabular}

\subsection{Cellulose saccharification}

The saccharification study was done on pure carboxymethyl cellulose (CMC). This was done to verify hydrolysis of pure cellulose by the cellulase enzyme produced by the isolate. $5 \mathrm{~g}$ CMC was treated with $20 \mathrm{ml}$ crude enzyme against control as water. After 48 hours of incubation at $50^{\circ} \mathrm{C}$, sample CMCase was liquefied as compared to control (shown in Figure 5). $23.42 \%$ hydrolysis of pure cellulose was observed with THS 8 crude enzyme broth. FPU of the crude enzyme was 0.0534

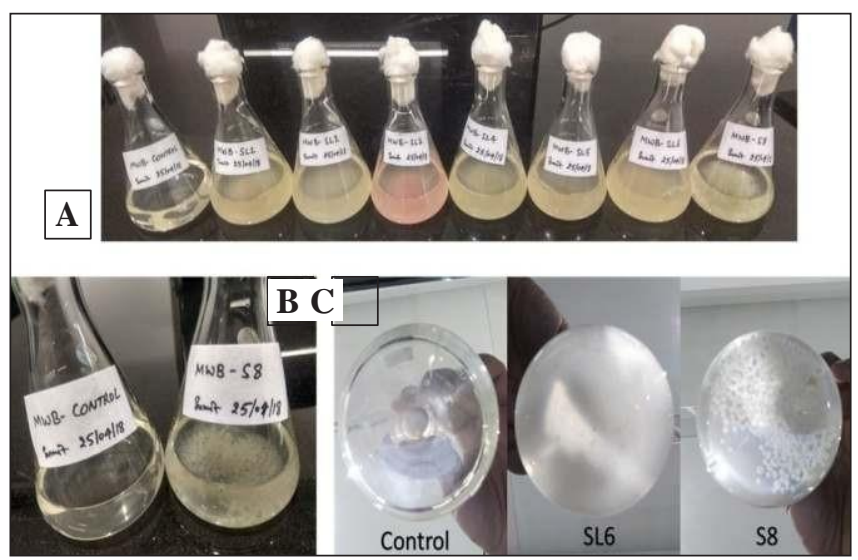

Figure 4:(A) Fungal isolates in 1\% CMC broth, (B) S8 culture against control, (C) Observation of fungal pellets in $\mathrm{S} 8$ as compared to SL6.

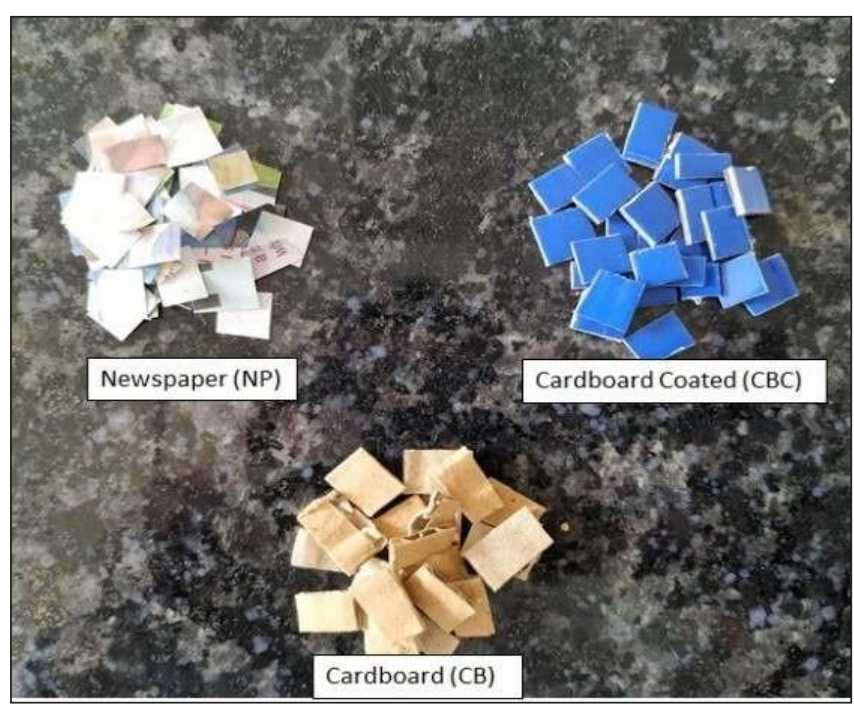

Figure 6: Hydrolysis of pure cellulose by using crude enzyme.
Table 2. FPU/ml of different isolates on MW medium with $1 \% \mathrm{CMC}$.

\begin{tabular}{|l|l|}
\hline Sample Name & FPU/ml \\
\hline SL1 & 0.1150 \\
\hline SL2 & 0.1336 \\
\hline SL3 & 0.1460 \\
\hline SL4 & 0.1596 \\
\hline SL5 & 0.1534 \\
\hline SL6 & 0.1348 \\
\hline S8 & 0.1658 \\
\hline
\end{tabular}

U/g of cellulose. Herr and Dieter used $10 \%$ cellulose suspension for hydrolysis by crude enzyme and resulted in a $40 \%$ hydrolysis. However, in this study, the suspension was $20 \%$ and hydrolysis was nearly similar to $10 \%$ cellulose suspension used by Herr and Dieter [30].

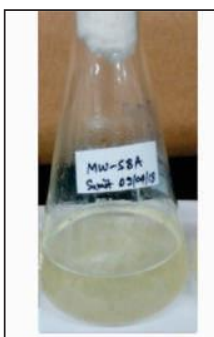

Broth for enayme

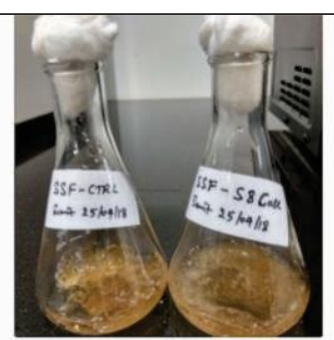

After 24 Hours

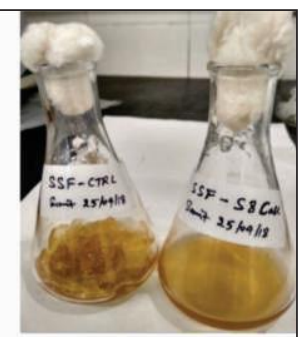

After 48 Hours

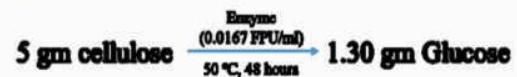

$23.42 \%$ hydrolydyis was echievod at $20 \%$ solid loeding $(0.0534 \mathrm{FPU} / \mathrm{g}$ of colluloee).

Figure 5: Hydrolysis of pure cellulose by using crude enzyme.

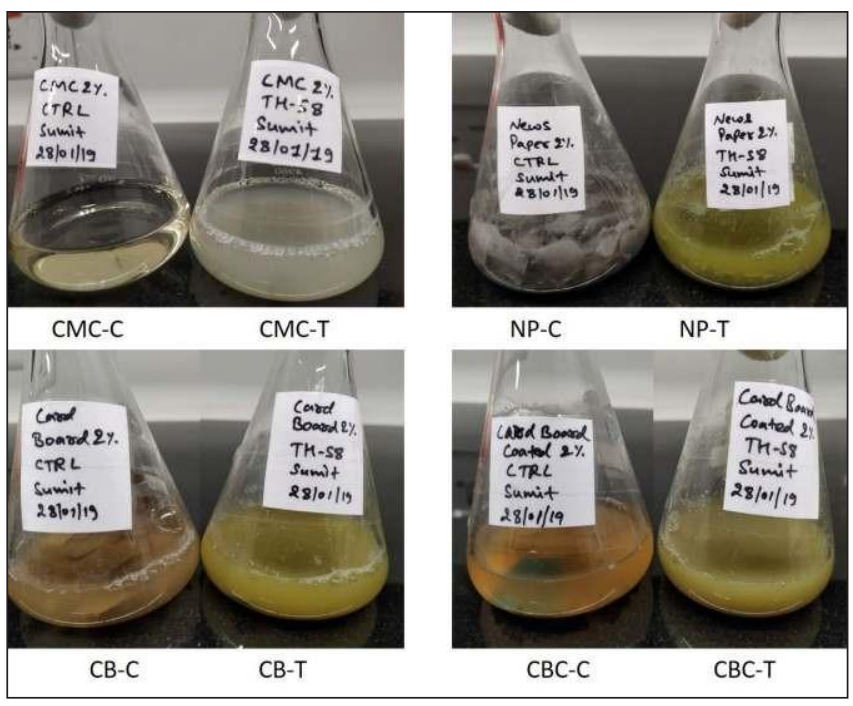

Figure 7: Comparative growth difference between control (C) and treated (T) and cellulase production in MW medium. 


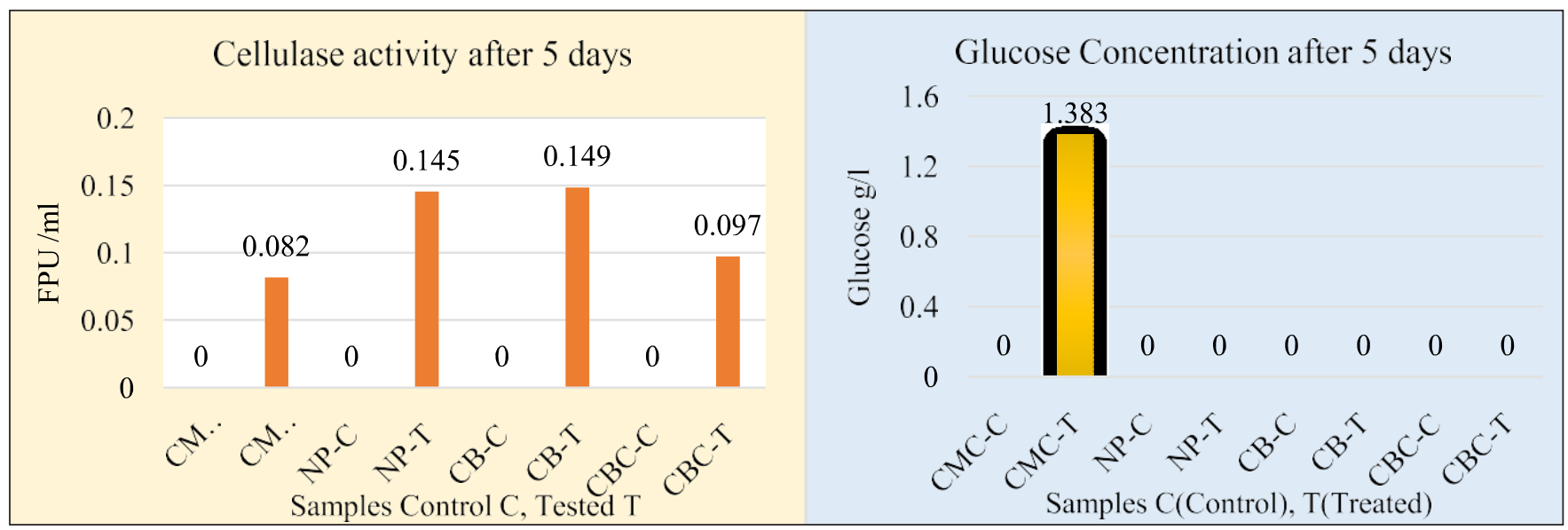

Figure 8: Left: Cellulase activity in FPU/ml in different substrates, Right: Glucose concentration after 5 days of incubation in the different samples.

\subsection{Paper waste utilization}

The use of the cheapest cellulose source was a major objective of this study. Therefore, 3 kinds of paper waste (Figure 6) as NP, CB, and CBC along with CMC was tested for cellulase production. Figure 7 depicts comparative growth differences in different substrates provided. The enzyme activity was found higher in NP, CB and CBC $(0.145$, 0.149and $0.097 \mathrm{FPU} / \mathrm{ml})$ as compared to the CMC $(0.082$ FPU/ml) as shown in Figure 8(left side). The newspaper and cardboard waste samples showed nearly similar cellulase activity. Cardboard is preferable because it is free from ink and dye and mostly dumped as waste while newspapers are used for other purposes too. The consumption of sugar and its release was also estimated. It was found that sugar was left in CMC-T (Treated) as $1.383 \mathrm{~g} / \mathrm{l}$, which can cause the feedback inhibition for the production of the enzyme in the CMC-T sample (Figure 8 right side). Ahlam et al., also showed the utilization of cardboard waste nearly $25 \mathrm{gm} / 1$ of the substrate with $2.95 \mathrm{FPU} / \mathrm{ml}$, which is quite higher than the observation done in this study. Here, direct cardboard was used as a substrate, while Ahlam et al., used $1 \% \quad \mathrm{H}_{2} \mathrm{SO}_{4}$ for pretreatment first, then further for enzymatic hydrolysis [31]. Similarly, newspaper, filter paper and other substrates were also tested for cellulose hydrolysis [32]. Here in this study, maximum enzyme activity was found with cardboard substrate i.e. 0.149 FPU/ml.

\subsection{Cardboard utilization for cellulase production}

It was found that the cardboard is a good substrate for enzyme production, as it showed maximum enzyme activity. So, the experiment was done in triplicates ( $\mathrm{CBA}, \mathrm{CBB}$, and $\mathrm{CBC}$ ) with cardboard used as substrate (Figure 9 left side). Here, $2 \%$ of cardboard was suspended in MW medium treated with THS 8 for 7 days at $30^{\circ} \mathrm{C}$ measured as the average maximum of $0.27 \mathrm{FPU} / \mathrm{ml}$ (Figure 9 right side). There was around $60 \%$ degradation of substrate observed with respect to remaining solid wet weight as shown in Figure 10.
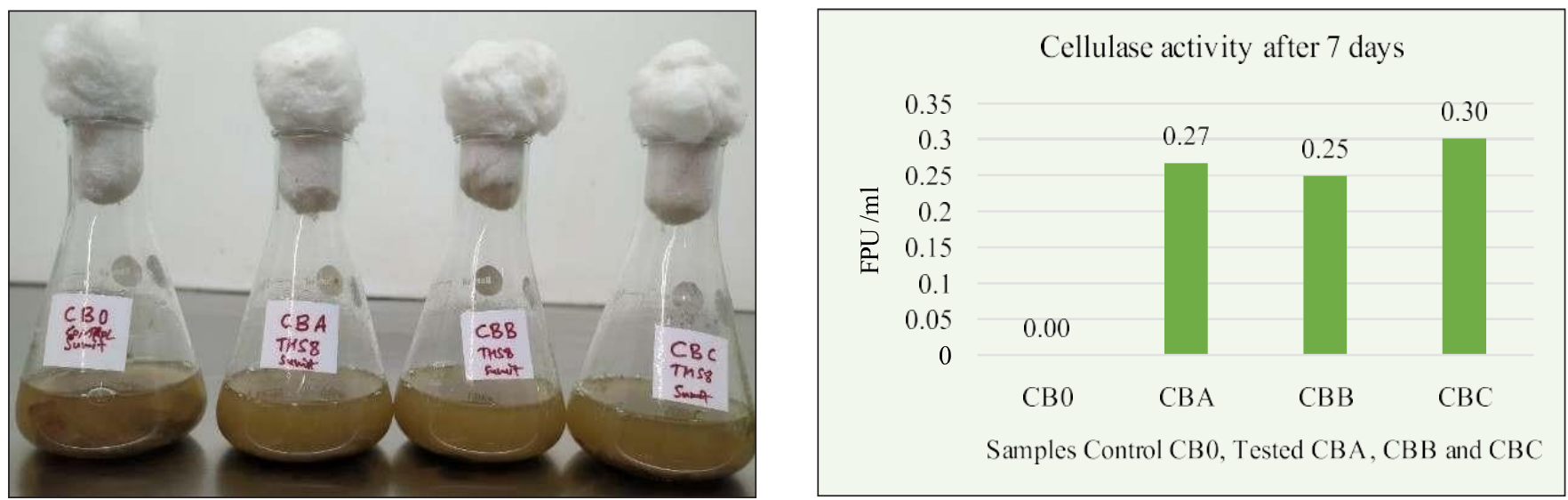

Figure 9: Left: Growth of the S8 in cardboard medium after 7 days, Right: Cellulase enzyme activity measured in cardboard medium cultures in triplicate: $\mathrm{CBO}$ is controlled, $\mathrm{CBA}, \mathrm{CBB}$, and $\mathrm{CBC}$ are the grown cultures. 


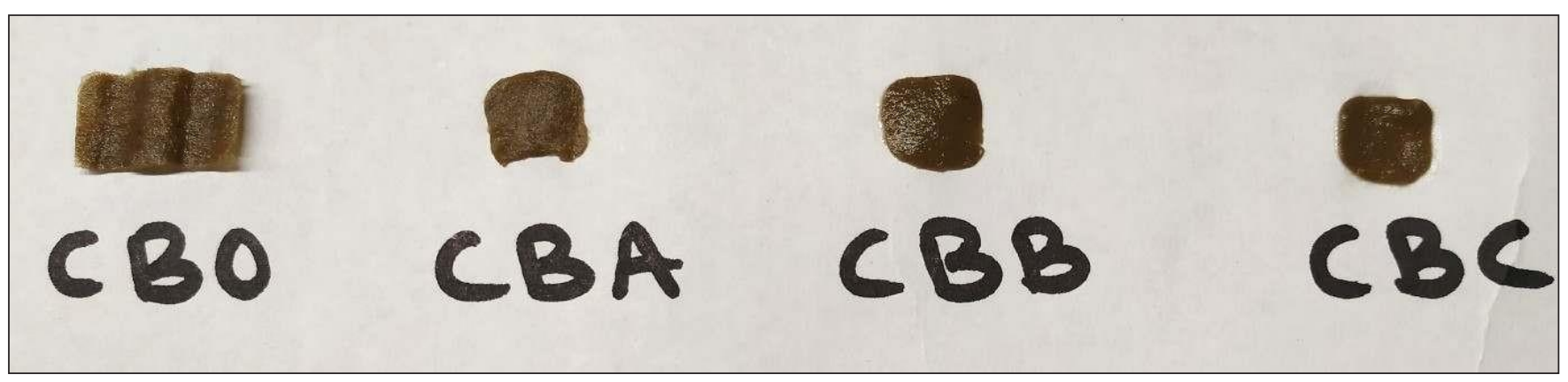

Figure 10: Degradation of the pure cardboard substrate: First left control (CBO) and the other three are samples in triplicate treated with the enzyme.

\subsection{Solid-state fermentation with cardboard}

Growth of mycelium on the cardboard waste as solid support was observed with nearly $85 \%$ moisture developed by the spore suspension on the substrate. Solid-state fermentation was previously used for cellulase production by using Trichoderma reesei QMY-1 with FPU as $17 \mathrm{U} / \mathrm{ml}$ [33]. The

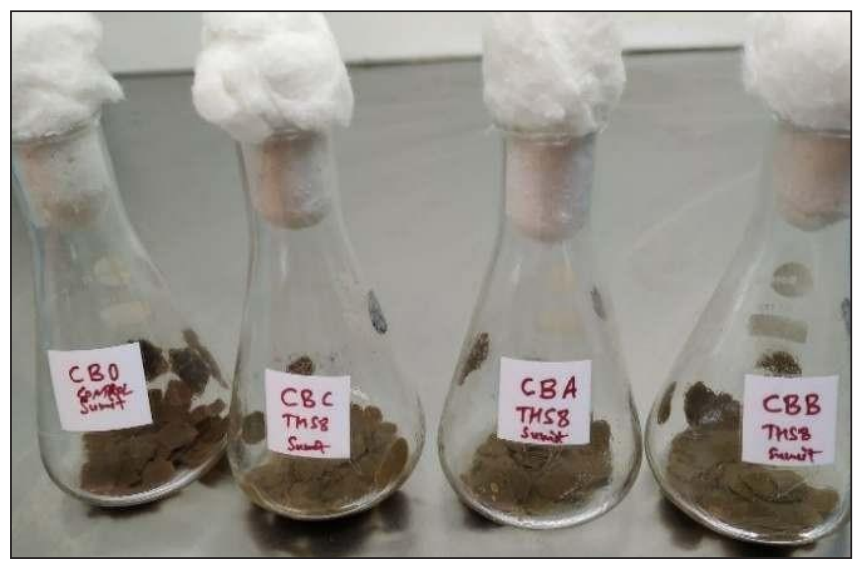

purpose of this study was to determine whether it is feasible to grow the fungus on solid cardboard or not. After 7 days of static incubation, the growth was observed on the medium and visually compared against control. Figure 11 clearly showed very high growth of isolate THS8 as green-colored patches on the wet cardboard.

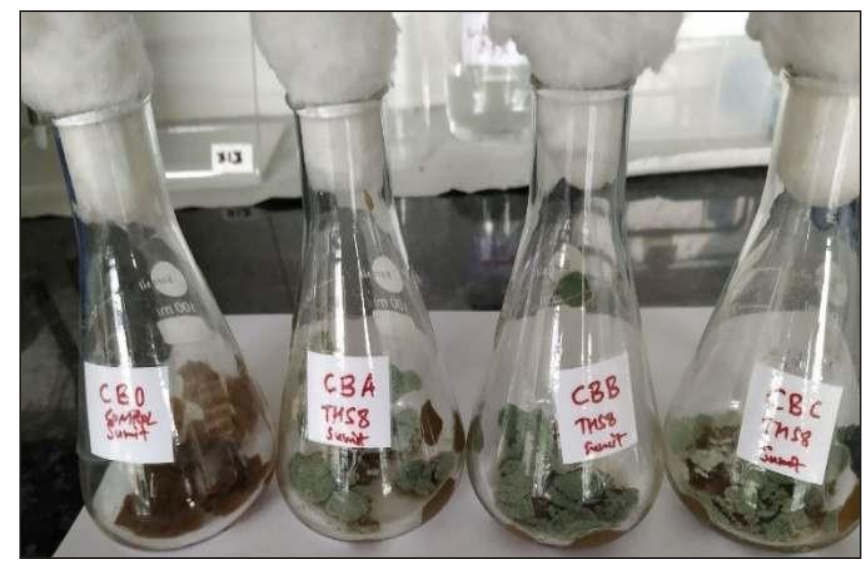

Figure 11: The solid-state fermentation of the isolate S8 on waste cardboard (Left: at zero-day Right: after 7 days).

\subsection{Substrate concentration optimization for cellulase and kinetic modeling}

Usually, with the increase in the substrate, there should be an increase in product yield. However, in the case of cellulases, feedback inhibition due to the product was observed. When the product is produced in a higher amount, the feedback inhibition occurs. A similar case was found in this study during substrate optimization of cardboard concentration. However, an increase in the activity was observed from day 2 to day 6 . While enzyme production was not increased much due to feedback inhibition by glucose concentration, it was found higher in more concentrated substrate samples. There was a substantial increase in glucose concentration after 6 days as $0.10,0.10,0.11,0.12,0.19,0.56 \mathrm{~g} / \mathrm{l}$ in 5, 10, 20, 30,40 and $50 \mathrm{~g} / \mathrm{l}$ samples respectively. Maximum enzyme activity was found to be $0.117 \mathrm{FPU} / \mathrm{ml}$ in $50 \mathrm{~g} / \mathrm{l}$ samples, but it was reduced due to higher glucose feedback inhibition (Figure
12). Meanwhile, inhibition was lower and nearly similar up to $30 \mathrm{~g} / \mathrm{l}$ sample. The $\mu_{\max }^{\mathrm{E}}$ and $\mathrm{K}_{\mathrm{s}}^{\mathrm{E}}$ were calculated as $14.93 \mathrm{~min}^{-1}$ and 0.022 respectively by using slope and intercept values of Figure 13. Similarly, other kinetic parameters like $\mathrm{K}_{\mathrm{m}}$ and Vmax were measured by Shafique et. al. by using Trichoderma viride FCBP-142 with 0.6 and 8.33 values respectively [34].

\subsection{Morphological identification}

During the initial 2 days of inoculation, the mycelium grown as white clouds then, after maturity, the color change to dark green (Figure 14A), which showed the similarity with Trichoderma hazaricum [35]. However, spores shown under the microscope are oval (Figure 14B), nearly $6.250 \mu \mathrm{m}$ in length and $3.125 \mu \mathrm{m}$ in width as measured with the scale bar after zooming at $8 \times$ from an image captured at $40 x$ objective. Conidial spores count was $\sim 5.42 \times 10^{6}$ per $\mathrm{ml}$. 

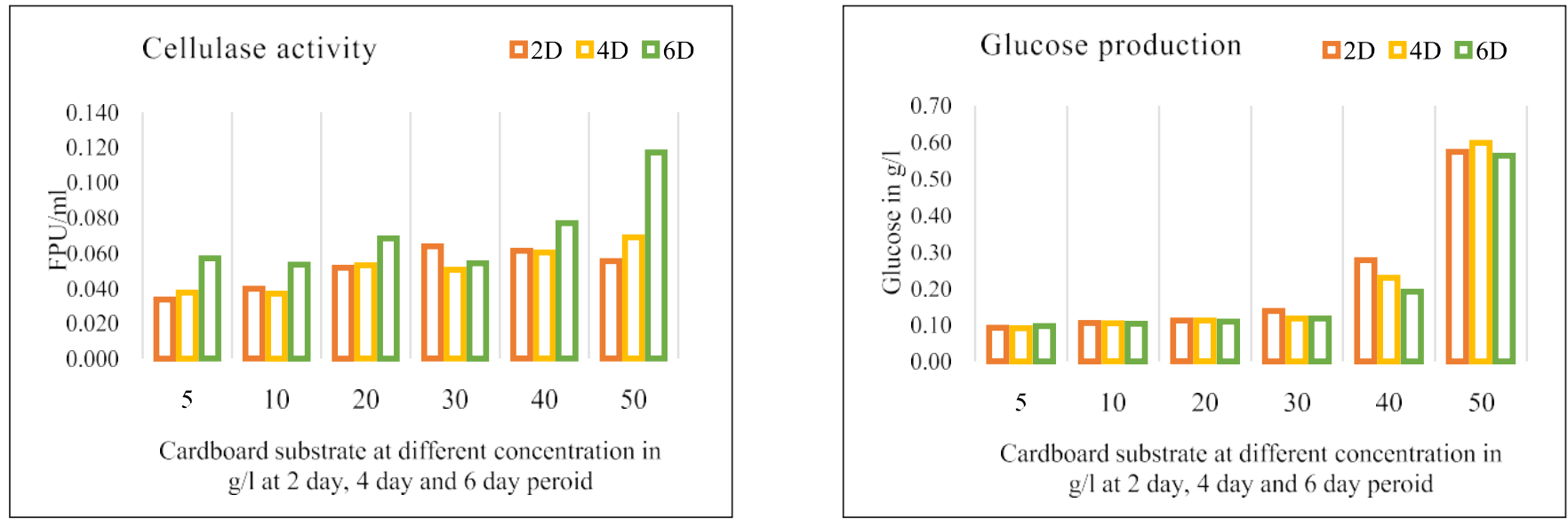

Figure 12: Left: Cellulase activity in FPU/ml in different concentrations of cardboard substrate Right: The glucose concentration of samples grown till 6 days of incubation with different concentration of substrate in g/l
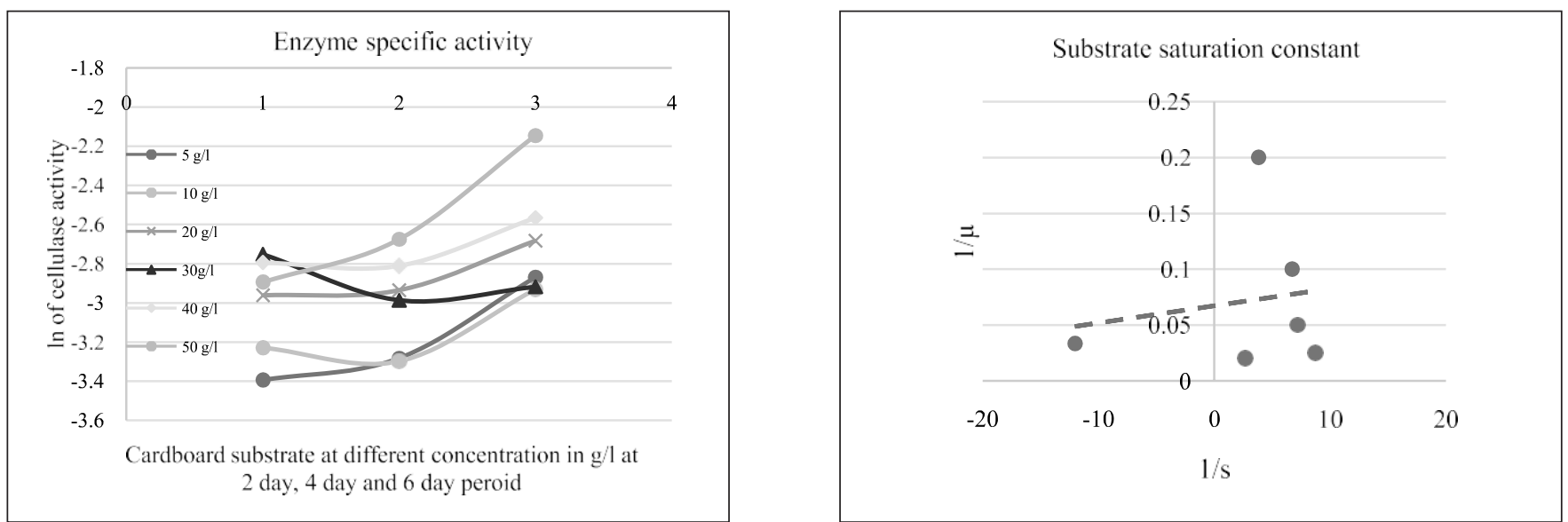

Figure 13: Left:Cellulase enzyme-specific activity measured as $\mu$ against each substrate over the time 2-day, 4 days and 6 days. Right: Substrate saturation constant $\mathrm{KsE}$ value determination by plotting $1 / \mu$ against $1 / \mathrm{s}$ values.
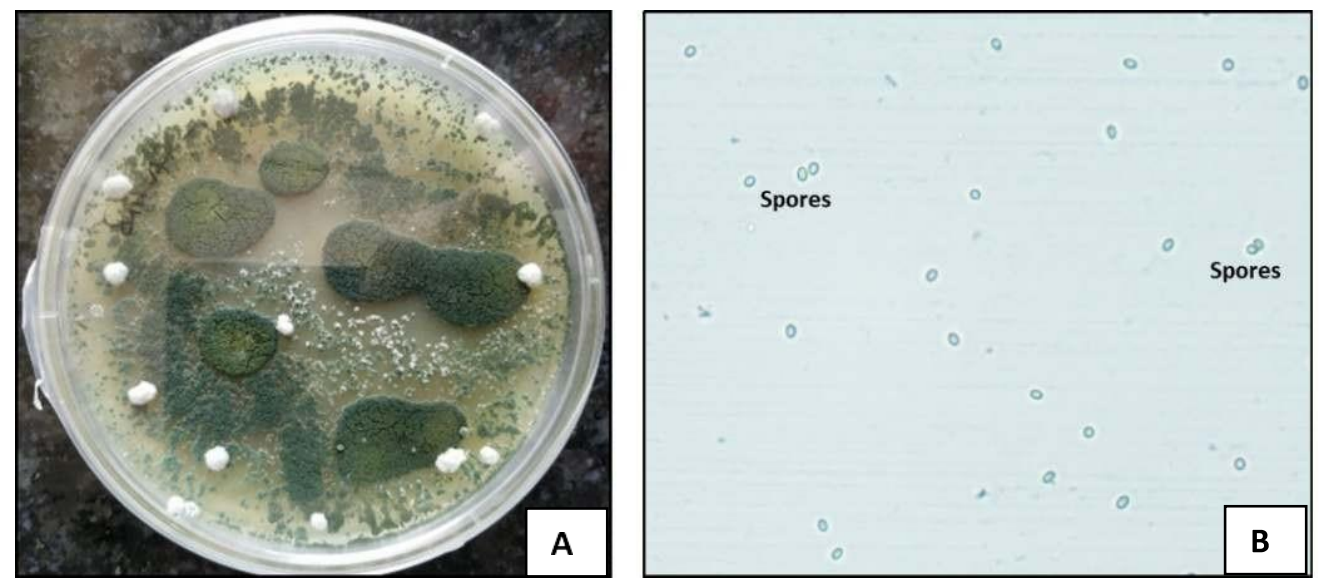

Figure 14: (A) Morphological identification of cellulase producing isolated fungi THS8. (B) microscopic image of conidial spores.

\section{Conclusion}

Application of paper waste for cellulase production at an industrial scale can be promising for reducing the cost of the enzyme as well as for waste management. This study signifies the use of cardboard waste as pure cellulosic feedstock replacement, which can contribute a cost-effective approach 
with higher cellulase enzyme production as compared to pure carboxymethyl cellulose. According to the results, isolated THS8 fungal strain was the best cellulase producing strain. The strain was capable of degrading nearly $60 \%$ of the cardboard waste during the study period and showed maximum cellulase activity of $0.27 \mathrm{FPU} / \mathrm{ml}$, which is a good start for its large-scale production after further process optimization. In conclusion, the cardboard waste is a very good potential source of cellulose substrate for cellulases production, irrespective of the dyes or ink it contains. It is more valuable because it can reduce the whole production cost and the process becomes simpler.

\section{Acknowledgement}

The authors are thankful to Bennett University for providing the necessary financial assistance to complete this study.

\section{References}

1. Anwar Z, Gulfraz M, Irshad M. Agro-industrial lignocellulosic biomass a key to unlock the future bioenergy: a brief review. Journal of Radiation Research and Applied Sciences. 2014 Apr 1;7(2):163-73.

2 Aditiya HB, Mahlia TM, Chong WT, Nur H, Sebayang AH. Second generation bioethanol production: A critical review. Renewable and Sustainable Energy Reviews. 2016 Dec 1;66:631-53.

3. Balan V. Current challenges in commercially producing biofuels from lignocellulosic biomass. ISRN Biotechnology. 2014 May 5;2014.

4 Nanda S, A Kozinski J, K Dalai A. Lignocellulosic biomass: a review of conversion technologies and fuel products. Current Biochemical Engineering. 2016 Apr $1 ; 3(1): 24-36$

5. Tomas-Pejo E, Oliva JM, Ballesteros M. Realistic approach for full-scale bioethanol production from lignocellulose: A Review. Journal of Scientific and Industrial Research. 2008 June 6;67(11):874-84.

6. Watkins D, Nuruddin M, Hosur M, Tcherbi-Narteh A, Jeelani S. Extraction and characterization of lignin from different biomass resources. Journal of Materials Research and Technology. 2015 Jan 1;4(1):26-32.

7. Madadi M, Tu Y, Abbas A. Recent status on enzymatic saccharification of lignocellulosic biomass for bioethanol production. Electronic Journal of Biology. 2017;13(2):135-43.

8 Saini R, Saini JK, Adsul M, Patel AK, Mathur A, Tuli D, Singhania RR. Enhanced cellulase production by Penicilliumoxalicum for bio-ethanol application. Bioresource Technology. 2015 Jul 1;188:240-6.

9. Lan TQ, Wei D, Yang ST, Liu X. Enhanced cellulase production by Trichoderma viride in a rotating fibrous bed bioreactor. Bioresource Technology. 2013 Apr 1;133:175-82.
10. Lou H, Zeng M, Hu Q, Cai C, Lin X, Qiu X, Yang D, Pang Y. Nonionic surfactants enhanced enzymatic hydrolysis of cellulose by reducing cellulase deactivation caused by shear force and air-liquid interface. Bioresource Technology. 2018 Feb 1;249:1-8.

11. Vu VH, Pham TA, Kim K. Improvement of fungal cellulase production by mutation and optimization of solid state fermentation. Mycobiology. 2011 Mar 1;39(1):20-5.

12 Cheng Y, Song X, Qin Y, Qu Y. Genome shuffling i mproves production of cellulase by Penicilliumdecumbens JU-A10. Journal of Applied Microbiology. 2009Dec;107(6):1837-46.

13. Wang Z, Lin X, Li P, Zhang J, Wang S, Ma $\mathbf{H}$. Effects of low intensity ultrasound on cellulase pretreatment. Bioresource Technology. 2012 Aug 1;117:222-7.

14 Adsul M, Sharma B, Singhania RR, Saini JK, Sharma A, Mathur A, Gupta R, Tuli DK. Blending of cellulolytic enzyme preparations from different fungal sources for improved cellulose hydrolysis by increasing synergism. R S C Advances. 2014;4(84):44726-32.

15. Azhar SH, Abdulla R, Jambo SA, Marbawi H, Gansau JA, Faik AA, Rodrigues KF. Yeasts in sustainable bioethanol production: A Review. Biochemistry and Biophysics Reports. 2017 Jul 1;10:52-61.

16. Singh N, Mathur AS, Tuli DK, Gupta RP, Barrow CJ, Puri M. Cellulosic ethanol production via consolidated bioprocessing by a novel thermophilic anaerobic bacterium isolated from a Himalayan hot spring. Biotechnology for Biofuels. 2017 Dec;10(1):73.

17. Walker GM, Stewart GG. Saccharomyces cerevisiae in the production of fermented beverages. Beverages. 2016 Dec;2(4):30.

18. Lane MM, Morrissey JP. Kluyveromycesmarxianus: a yeast emerging from its sister's shadow. Fungal Biology Reviews. 2010 Feb 1;24(1-2):17-26.

19. Yang S, Fei Q, Zhang Y, Contreras LM, Utturkar SM, Brown SD, Himmel ME, Zhang $M$. Zymomonasmobilis as a model system for production of biofuels and biochemicals. Microbial biotechnology. 2016 Nov;9(6):699-717.

20. McMillan JD. Xylose fermentation to ethanol. A review. National Renewable Energy Lab., Golden, CO (United States); 1993 Jan 1.

21. Ostergaard S, Olsson L, Nielsen J. Metabolic engineering of Saccharomyces cerevisiae. Microbiol. Molecular Biology Reviews. 2000 Mar 1;64(1):3450 . 
22 Brat D, Boles E, Wiedemann B. Functional expression of a bacterial xylose isomerase in Saccharomyces cerevisiae. Applied and Environmental Microbiology. 2009 Apr 15;75(8):2304-11.

23. Priyanka P, Yuvraj C, Farha S, Aranganathan V. Isolation of cellulose degrading fungi from soil and optimization for cellulase production using carboxy methyl cellulose. International Journal of Life Science and Pharma Research. 2017 Jan 1;7(1):56-60.

24 Bakar NA, Abd-Aziz S, Hassan MA, Ghazali FM. Isolation and selection of appropriate cellulolytic mixed microbial cultures for cellulases production from oil palm empty fruit bunch. Biotechnology. 2010;9(1):73-8.

25. Ghose TK. Measurement of cellulase activities. Pure and applied Chemistry. 1987 Jan 1;59(2):257-68.

26. https://en.wikibooks.org/wiki/ Structural_ Biochemistry/Enzyme/Michaelis_and_Menten_Equa tion (accessed on date 05/12/2019)

27. Hendricks CW, Doyle JD, Hugley B. A new solid medium for enumerating cellulose-utilizing bacteria in soil. Applied and Environmental Microbiology. 1995 May1;61(5):2016-9.

28. Florencio C, Couri S, Farinas CS. Correlation between agar plate screening and solid-state fermentation for the prediction of cellulase production by Trichoderma strains. Enzyme Research. 2012;2012.

29. Gusakov AV, Kondratyeva EG, Sinitsyn AP. Comparison of two methods for assaying reducing sugars in the determination of carbohydrase activities. International Journal of Analytical Chemistry. 2011;2011.

30. Herr D. Conversion of cellulose to glucose with cellulase of Trichoderma viride ITCC-1433. Biotechnology and Bioengineering. 1980 Aug;22(8):1601-12.

31. Al Azkawi AS, Sivakumar N, Al Bahry S. Bioprocessing of cardboard waste for cellulase production. Biomass Conversion and Biorefinery. 2018 Sep 1;8(3):597-606.

32 Van Wyk JP, Mogale MA, Moroka KS. Bioconversion of waste paper materials to sugars: An application illustrating the environmental benefit of enzymes. Biochemical Education. 1999 Oct;27(4):227-8.

33. Chahal DS. Solid-state fermentation with Trichoderma reesei for cellulase production. Applied and Environmental Microbiology. 1985 Jan 1;49(1):205-10.

34. Shafique S, Shafique S. Kinetic study of partially purified cellulase enzyme produced by Trichoderma viride FCBP-142 and its hyperactive mutants. Microbiology. 2011 Jun 1;80(3):363.

35. Sekhar YC, Ahammed SK, Prasad TN, Devi RS. Identification of Trichoderma species based on morphological characters isolated from rhizosphere of groundnut (Arachishypogaea L). International Journal of Environmental Science and Technology. 2017;6:2056-63. 